\title{
Leading Dental Journals Availability through Academic Network of Serbia
}

\author{
Jelena Jaćimović1, Slavoljub Živković² \\ ${ }^{1}$ Central Library, School of Dentistry, University of Belgrade, Belgrade, Serbia; \\ ${ }^{2}$ Department of Restorative Dentistry and Endodontics, School of Dentistry, University of Belgrade, Belgrade, Serbia
}

\begin{abstract}
SUMMARY
In the last century a great progress was noted in all scientific disciplines. With the increasing number of scientific research, researchers and investment, the number of publications has grown exponentially. Besides, the development of information technologies and the emergence of the Internet, communication between scientists as well as the traditional roles assigned to the institutions responsible for information processing and provision has been changed. Due to the rapidly increasing subscription rates, libraries, although the primary participants in the scholarly communication process, lose their ability to meet user information needs. In order to overcome commercialization of scholarly publishing, libraries intensify use of different electronic resources, coordinate acquisition policy and form consortia. In November 2001, leading research libraries in Serbia launched an initiative to form the Consortium for Coordinated Acquisition of Serbian Libraries (KoBSON). Subscribed services, funded by the Ministry of Science and Technological Development of Serbia, currently include over 35,000 scientific journals, about 40,000 books and several citation databases. In the field of Dentistry, Oral Surgery and Medicine, $73.4 \%$ of total number of the most relevant dental journals is available in electronic form to Serbian academic community. This article presents a comprehensive overview of basic information about available journals: impact factor, productivity, publication continuity and frequency, language, services that they are available through, size of archives and existing formats. At present Serbian academic institutions have access to more than two thirds of the world's most relevant dental journals, which justifies the Consortium founders' initial idea of wide accessibility of scientific information and requires greater involvement of librarians in introducing available services to researchers in order to ensure their full utilization.
\end{abstract}

Keywords: electronic journals; dentistry; library consortia; electronic access

\section{INTRODUCTION}

Communication is the essence of science and critical to the development of scientific activity. Scientists not only communicate results to their colleagues through journal articles and conference presentations, but also depend on previously published works to state future research methodology. Scientific communication, as a process of communicating and providing details of the various research stages within a certain time frames, subsumes all forms of transformation from initial concept to integration of the research as a generally accepted scientific knowledge. Exchange of notions and findings - communication - is present at all stages of the research process [1].

Since the late 17th century, when the first scientific journals appeared, publishing research is basis of formal scientific communication. During the following centuries, with the development of information technology, the structure of the scientific communication system has experienced profound changes, followed by the transformation of the actors involved functions and roles. While the scholarly publishing industry is driven by the need of scientists to "publish or perish", commercial publishing houses are taking control over the system, transforming it to a highly profitable business.

Publisher's exploitation of the scientific communication domain brings to a crisis in the system. Specifically, the researchers lose their authority over the published articles giving exclusive rights to publishers. This leads to paradoxical situation in which ministries of science and higher education are spending huge amounts of money to support scientific research, and then again pay large sums in order to make those results available to the very same scientists who have produced them. Libraries, as the primary participants in the scholarly communication, are increasingly losing their ability to meet researchers' growing information needs.

Traditionally academic libraries were maintaining print journal collections to support their institution's educational and research activities. For example, in the mid-1980s more than one hundred of dental journal titles were available to teaching and research staff in the School of Dentistry University of Belgrade. However, in 2000 only $3.8 \%$ of that number remains accessible, primarily due to increased journal subscription rates, stagnant library budgets and high inflation at the end of last century (Graph 1). 
In order to solve the problem, in collection development libraries turn from the ownership to access, from "just in case" to "just in time" principle. Therefore they increase the use of various electronic resources of scientific information, obtaining timely access (regardless of distance and number of users) and saving the room for existing physical resources [2]. Also, libraries coordinate acquisition policy with similar libraries and form consortia based on a mutual goal and interest.

\section{CONSORTIUM FOR COORDINATED ACQUISITION OF SERBIAN LIBRARIES (KoBSON)}

First attempt to organize Serbian libraries in such a way as to facilitate knowledge sharing at a much cheaper rate was the Consortium for Coordinated Acquisition (KoBSON) [3]. In November 2001 the directors of the main research libraries as well as presidents of the Library Associations of main academic and public libraries of Serbia initiated forming of a Serbian Library Consortium. National library of Serbia is the official representative in the negotiations with both publishers and charged ministries. The entire subscription system is funded solely through the Ministry of Science and Technological Development of the Republic of Serbia. Thanks to the Consortium membership in eIFL project (Electronic Information for Libraries), it is enabled access to multiple databases and electronic services, funding the Interlibrary Loan as well as purchasing of international scientific journals in paper form. In acquisition policy planning, mostly is taken care of scientific areas mainly investigated in our research and educational institutions. Through its website, the Center for Scientific Information at the National Library of Serbia provides the necessary information about the current subscriptions, projects that the Consortium participates in, as well as the forthcoming lectures and presentations. In order to effectively meet users' needs for a 24/7 available information, university and institute employees have an opportunity to sign a personal licence, use KoBSON and search all available services via commercial Internet providers.
Online access to a great number of full-text databases, relevant and worldwide valuable scientific research tool, is provided for all Serbian research and educational institutions through the Academic Network. Subscribed services include over 35,000 international scientific journals in electronic or paper form, and since 2006 about 40,000 book titles, as well as several citation databases. As a result of coordinated acquisition, Serbian academic community at present gets much more subscribed high quality international scientific journals for less investment [4]. Many of these journals are highly cited titles, and citation criteria is widely used in scientific policy management, especially as the main indicator of scientific journals' influence or researcher's performance and progress. So the availability of relevant scientific journals, as well as the ability of authors to publish papers in them, are of great importance for researchers nowadays.

\section{ISI - THOMSON CITATION INDEXES}

ISI (Institute for Scientific Information) - Thomson Reuters' citation indexes, initially used as an alternative means for literature search, today represent worldwide prominent source of scientific information. Service Web of Science, containing all three citation indexes (Science Citation Index, Social Sciences Citation Index, Arts \& Humanities Citation Index), covers over 10,000 of the highest impact scientific journals, as well as over 120,000 international conference proceedings [5]. This ISI - Thomson product provides access to bibliographic information of articles that have been published since 1996 until today. For all journals listed in these citation databases, as well as for cited journals, impact factors have been calculated once a year and published in the Journal Citation Reports (JCR) since 1975 . JCR, referencing more than 8,000 highly cited peer-reviewed titles from 3,300 diverse publishers, offers a systematic means for evaluating the world's leading journals and their influence on the entire research community [6].

As funding rates and the number of active researchers vary between scientific disciplines, which directly

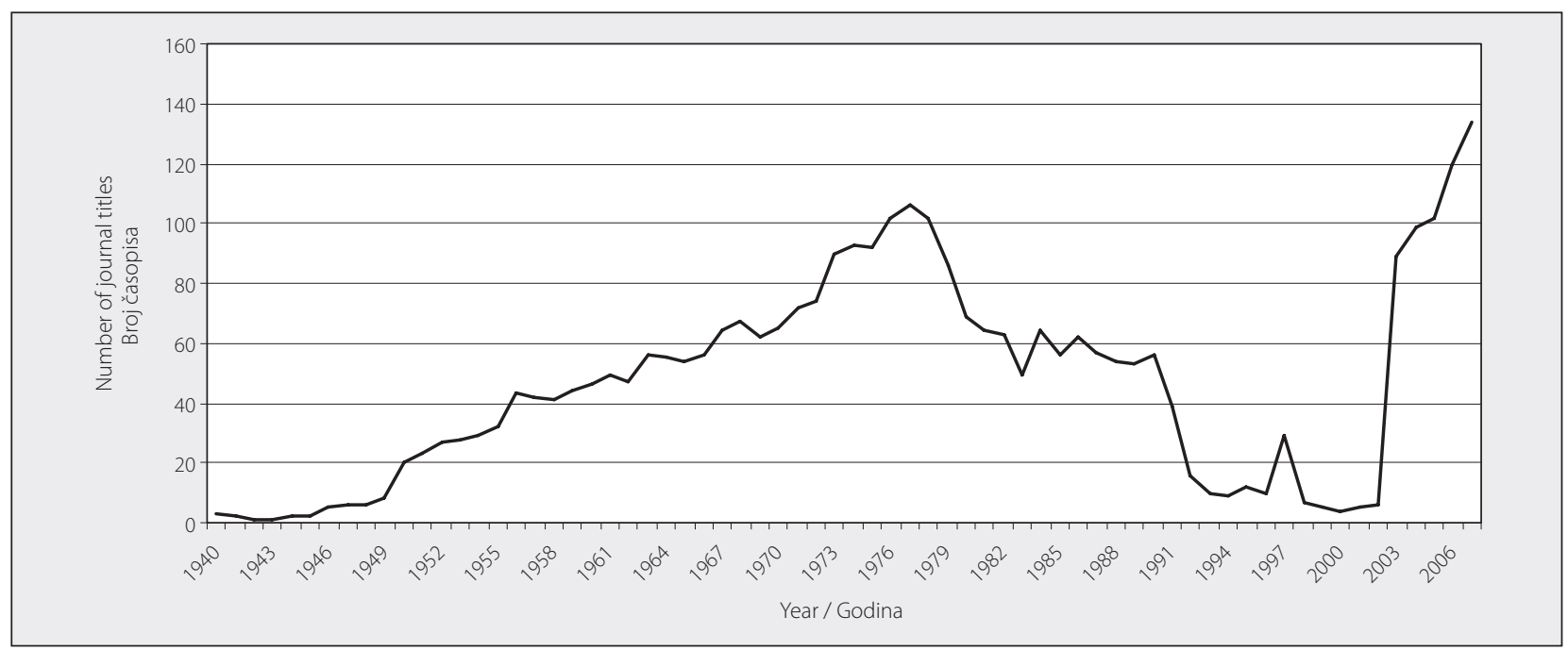

Graph 1. The number of subscribed journals by School of Dentistry University of Belgrade

Grafikon 1. Broj časopisa na koje je pretplaćen Stomatološki fakultet Univerziteta u Beogradu 
affects citedness, and the levels of the highest journal impact factors are also discipline-dependent. Therefore, this measure is only relevant to compare journals within a respective scientific field. All journals, for which impact factor is calculated, are distributed among more than two hundred categories (disciplines according to ISI - JCR categorization).

\section{LEADING DENTAL JOURNALS}

In the field of Dentistry, Oral Surgery and Medicine, there are 64 international peer-reviewed journals with impact factors. These most relevant dental journals pertain to other scientific disciplines too (Table 1).

Graph 2 shows increase in total number of Dentistry, Oral Surgery and Medicine journals in the period since 1998.

Between 2005 and 2009 the value of the discipline highest impact factor was not significantly changed and fluctuates from 3.493 to 3.933 .

Most of the leading dental journals are published in the US and the UK (62.5\%), Denmark (17.2\%), while only 9.3\% are issued in Western Europe. The remaining 11\% of the total number of journals are produced in Japan, Canada, Brazil, Taiwan and Australia.

The fact of great importance for each author is the total number of articles that journal publishes during the year. Within this discipline in 2009 the largest number of published articles had Oral Surgery, Oral Medicine, Oral Pathology, Oral Radiology and Endodontology (447) and Journal of Oral and Maxillofacial Surgery (424), while CRANIO - The Journal of Craniomandibular Practice issued only 8 articles.

\section{ELECTRONICALLY AVAILABLE DENTAL JOURNALS}

Out of 64 discipline journals, 47 titles provide online full-text access through the Academic Network of Serbia
Table 1. Dental journals categories

Tabela 1. Discipline časopisa iz oblasti stomatologije

\begin{tabular}{|c|c|}
\hline $\begin{array}{l}\text { Journal Citation Reports Subject Category } \\
\text { Predmetna disiplina prema Journal Citation Reports }\end{array}$ & $\begin{array}{c}\text { Number of } \\
\text { journals } \\
\text { Broj } \\
\text { časopisa }\end{array}$ \\
\hline $\begin{array}{l}\text { Dentistry, oral surgery and medicine } \\
\text { Stomatologija, oralna hirurgija i medicina }\end{array}$ & 64 \\
\hline $\begin{array}{l}\text { Surgery } \\
\text { Hirurgija }\end{array}$ & 4 \\
\hline $\begin{array}{l}\text { Materials science, biomaterials } \\
\text { Nauka o materijalima, biomaterijali }\end{array}$ & 2 \\
\hline $\begin{array}{l}\text { Education, scientific disciplines } \\
\text { Obrazovanje, naučne discipline }\end{array}$ & 1 \\
\hline $\begin{array}{l}\text { Geriatrics and gerontology } \\
\text { Gerijatrija i gerontologija }\end{array}$ & 1 \\
\hline $\begin{array}{l}\text { Immunology } \\
\text { Imunologija }\end{array}$ & 1 \\
\hline $\begin{array}{l}\text { Microbiology } \\
\text { Mikrobiologija }\end{array}$ & 1 \\
\hline $\begin{array}{l}\text { Oncology } \\
\text { Onkologija }\end{array}$ & 1 \\
\hline $\begin{array}{l}\text { Pathology } \\
\text { Patologija }\end{array}$ & 1 \\
\hline $\begin{array}{l}\text { Pediatrics } \\
\text { Pedijatrija }\end{array}$ & 1 \\
\hline $\begin{array}{l}\text { Public, environmental and occupational health } \\
\text { Zdravstvena zaštita, zaštita životne i radne sredine }\end{array}$ & 1 \\
\hline $\begin{array}{l}\text { Radiology, nuclear medicine and medical imaging } \\
\text { Radiologija, nuklearna medicina i medicinsko snimanje }\end{array}$ & 1 \\
\hline
\end{tabular}

(Table 2). These journals have long tradition and continuity of publishing. There are those that persist more than a century, such as British Dental Journal, published since 1880, and European Journal of Oral Sciences, which first appeared in 1893, but most of them emerged in 1980s. The youngest journal, published since 2006 by Elsevier, is Journal of Dental Sciences (Table 3).

Since English appears to be the universal language of communication, it is understandable that each of these online available journals is published in English. In addition to English, Archives of Oral Biology has its French and German editions. Journal of Orofacial Orthopedics is published in German and English, while Journal of Applied Oral Sciences has both English and Portuguese editions.

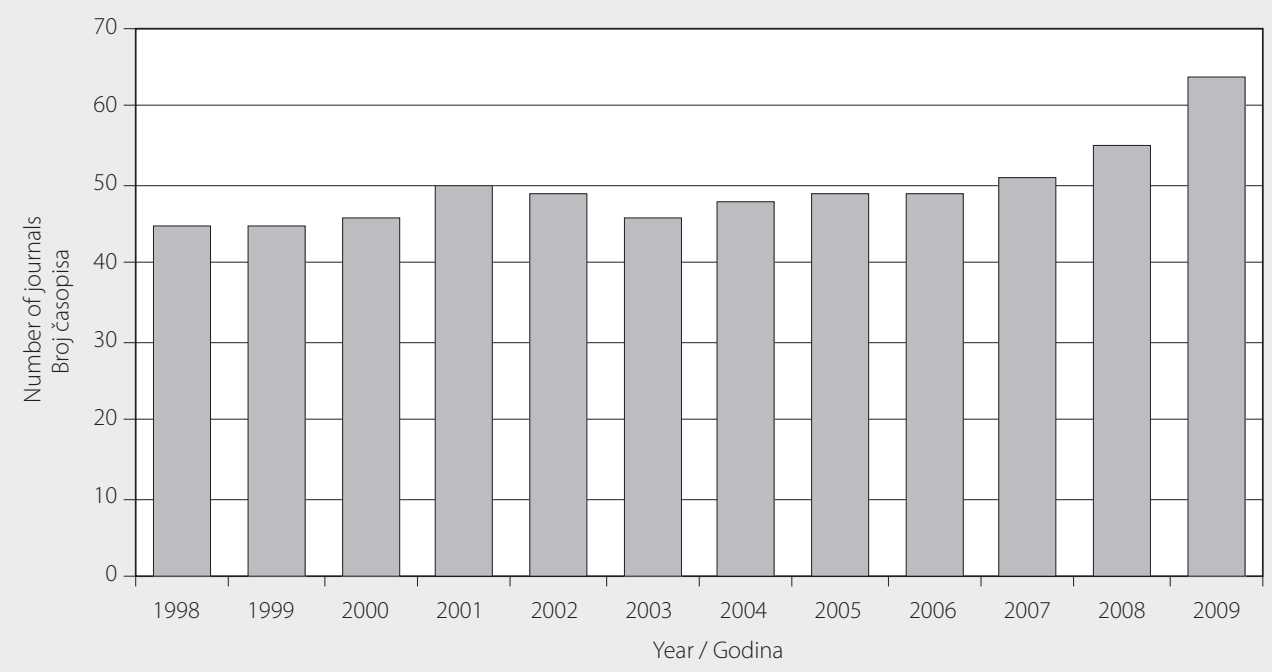

Graph 2. Total number of journals in Journal Citation Reports category Dentistry, Oral Surgery and Medicine Grafikon 2. Ukupan broj časopisa u kategoriji Stomatologija, oralna hirurgija i medicina u Journal Citation Reports 
Table 2. The list of dental journals available (A) online in full text via Academic Network, ranked by decreasing impact factor (IF; 2009)

Tabela 2. Lista elektronski dostupnih (D) stomatoloških časopisa u punom tekstu preko akademske mreže, rangiranih po opadajućem faktoru uticaja (FU; 2009)

\begin{tabular}{|c|c|c|c|}
\hline ISSN & \begin{tabular}{|l|} 
Journal \\
Naslov
\end{tabular} & $\begin{array}{l}\text { IF } \\
\text { FU }\end{array}$ & $\begin{array}{l}\text { A } \\
\text { D }\end{array}$ \\
\hline 0303-6979 & Journal of Clinical Periodontology & 3.549 & $\checkmark$ \\
\hline $0022-0345$ & Journal of Dental Research & 3.458 & $\checkmark$ \\
\hline $1368-8375$ & Oral Oncology & 3.123 & $\checkmark$ \\
\hline 0906-6713 & Periodontology 2000 & 3.027 & $\checkmark$ \\
\hline 0099-2399 & Journal of Endodontics & 2.953 & $x$ \\
\hline 0905-7161 & Clinical oral Implants Research & 2.920 & $\checkmark$ \\
\hline 0109-5641 & Dental Materials & 2.882 & $\checkmark$ \\
\hline $0008-6568$ & Caries Research & 2.462 & $\checkmark$ \\
\hline 1523-0899 & Clinical Implant Dentistry and Related Research & 2.452 & $\checkmark$ \\
\hline 0301-5661 & Community Dentistry and Oral Epidemiology & 2.418 & $\checkmark$ \\
\hline $0902-0055$ & Oral Microbiology and Immunology & 2.336 & $\checkmark$ \\
\hline $1432-6981$ & Clinical Oral Investigations & 2.233 & $\checkmark$ \\
\hline 0143-2885 & International Endodontic Journal & 2.223 & $\checkmark$ \\
\hline $0022-3492$ & Journal of Periodontology & 2.192 & $x$ \\
\hline $0904-2512$ & Journal of Oral Pathology and Medicine & 2.144 & $\checkmark$ \\
\hline $0300-5712$ & Journal of Dentistry & 2.000 & $\checkmark$ \\
\hline $0882-2786$ & $\begin{array}{l}\text { International Journal of Oral \& Maxillofacial } \\
\text { Implants }\end{array}$ & 1.978 & $x$ \\
\hline $0022-3484$ & Journal of Periodontal Research & 1.966 & $\checkmark$ \\
\hline 0909-8836 & European Journal of Oral Sciences & 1.956 & $\checkmark$ \\
\hline $1354-523 X$ & Oral Diseases & 1.922 & $\checkmark$ \\
\hline 0002-8177 & Journal of the American Dental Association & 1.726 & $\checkmark$ \\
\hline 0198-7569 & $\begin{array}{l}\text { International Journal of Periodontics \& Restorative } \\
\text { Dentistry }\end{array}$ & 1.702 & $x$ \\
\hline $0361-7734$ & Operative Dentistry & 1.683 & $x$ \\
\hline 0003-9969 & Archives of Oral Biology & 1.649 & $\checkmark$ \\
\hline $1461-5185$ & Journal of Adhesive Dentistry & 1.638 & $x$ \\
\hline $1601-6335$ & Orthodontics and Craniofacial Research & 1.607 & $\checkmark$ \\
\hline $0278-2391$ & Journal of Oral and Maxillofacial Surgery & 1.580 & $\checkmark$ \\
\hline $1056-6163$ & Implant Dentistry & 1.505 & $x$ \\
\hline $1079-2104$ & $\begin{array}{l}\text { Oral Surgery Oral Medicine Oral Pathology Oral } \\
\text { Radiology and Endodontology }\end{array}$ & 1.499 & $\checkmark$ \\
\hline $0305-182 X$ & Journal of Oral Rehabilitation & 1.483 & $\checkmark$ \\
\hline 0901-5027 & International Journal of Oral \& Maxillofacial Surgery & 1.444 & $\checkmark$ \\
\hline $0001-6357$ & Acta Odontologica Scandinavica & 1.412 & $\checkmark$ \\
\hline 0889-5406 & $\begin{array}{l}\text { American Journal of Orthodontics \& Dentofacial } \\
\text { Orthopedics }\end{array}$ & 1.327 & $\checkmark$ \\
\hline $0266-4356$ & British Journal of Oral \& Maxillofacial Surgery & 1.327 & $\checkmark$ \\
\hline $1600-4469$ & Dental Traumatology & 1.316 & $\checkmark$ \\
\hline 0894-8275 & American Journal of Dentistry & 1.314 & $x$ \\
\hline $1064-6655$ & Journal of Orofacial Pain & 1.263 & $x$ \\
\hline $1010-5182$ & Journal of Cranio-Maxillofacial Surgery & 1.252 & $\checkmark$ \\
\hline $0250-832 X$ & Dentomaxillofacial Radiology & 1.229 & $x$ \\
\hline 0893-2174 & International Journal of Prosthodontics & 1.227 & $x$ \\
\hline $0045-0421$ & Australian Dental Journal & 1.220 & $\checkmark$ \\
\hline $0022-3913$ & Journal of Prosthetic Dentistry & 1.215 & $\checkmark$ \\
\hline $0960-7439$ & International Journal of Paediatric Dentistry & 1.141 & $\checkmark$ \\
\hline 0007-0610 & British Dental Journal & 1.089 & $\checkmark$ \\
\hline 0022-0337 & Journal of Dental Education & 1.087 & $\checkmark$ \\
\hline 1396-5883 & European Journal of Dental Education & 1.024 & $\checkmark$ \\
\hline 0734-0664 & Gerodontology & 1.014 & $\checkmark$ \\
\hline 0141-5387 & European Journal of Orthodontics & 0.975 & $\checkmark$ \\
\hline $0265-539 X$ & Community Dental Health & 0.969 & $x$ \\
\hline $0022-4006$ & Journal of Public Health Dentistry & 0.961 & $\checkmark$ \\
\hline $1488-2159$ & Journal of the Canadian Dental Association & 0.959 & $\checkmark$ \\
\hline 0003-3219 & Angle Orthodontist & 0.937 & $\checkmark$ \\
\hline $0287-4547$ & Dental Materials Journal & 0.929 & $\checkmark$ \\
\hline 0347-9994 & Swedish Dental Journal & 0.927 & $x$ \\
\hline $1434-5293$ & Journal of Orofacial Orthopedics & 0.890 & $\checkmark$ \\
\hline $1055-6656$ & Cleft Palate-Craniofacial Journal & 0.884 & $\checkmark$ \\
\hline $1496-4155$ & Journal of Esthetic and Restorative Dentistry & 0.797 & $\checkmark$ \\
\hline $1618-1247$ & Odontology & 0.650 & $\checkmark$ \\
\hline 0033-6572 & Quintessence International & 0.635 & $x$ \\
\hline 0020-6539 & International Dental Journal & 0.632 & $x$ \\
\hline 0886-9634 & Cranio - The Journal of Craniomandibular Practice & 0.412 & $x$ \\
\hline $1678-7757$ & Journal of Applied Oral Science & 0.386 & $\checkmark$ \\
\hline 0035-1768 & $\begin{array}{l}\text { Revue de Stomatologie et de Chirurgie } \\
\text { Maxillo-Faciale }\end{array}$ & 0.349 & $x$ \\
\hline $1991-7902$ & Journal of Dental Sciences & 0.107 & $\checkmark$ \\
\hline
\end{tabular}

Journal of Clinical Periodontology gives only abstracts in German and French beside in English, whereas abstracts of articles published in Clinical Oral Implants Research are available in English, German, French, Spanish and Japanese language.

Journals publication frequency is mostly bimonthly. Furthermore some titles are published eight or ten times a year, whereas British Dental Journal is released even 24 times a year; Periodontology 2000 is published three times a year and Odontology only once (17 published articles in 2009) (Table 4).

Each of the available services provides online access to the electronic resources, using a wide variety of flexible search options (according to the specific field, journal title etc.), with possibility of narrowing/expanding search results by multiple criteria [7]. Table 5 shows list of services that allow viewing and downloading in extenso articles published in leading dental journals.

Table 3. The beginings of issues of individual journals

Tabela 3. Počeci izlaženja pojedinih časopisa

\begin{tabular}{|c|c|}
\hline $\begin{array}{c}\text { Period } \\
\text { Period }\end{array}$ & $\begin{array}{c}\text { Number of journals } \\
\text { Broj časopisa }\end{array}$ \\
\hline $1880-1900$ & $2(4.3 \%)$ \\
\hline $1900-1920$ & $4(8.5 \%)$ \\
\hline $1930-1940$ & $4(8.5 \%)$ \\
\hline $1940-1950$ & $3(6.4 \%)$ \\
\hline $1950-1960$ & $3(6.4 \%)$ \\
\hline $1960-1970$ & $6(12.8 \%)$ \\
\hline $1970-1980$ & $10(21.3 \%)$ \\
\hline $1980-1990$ & $6(12.8 \%)$ \\
\hline $1990-2010$ & $9(19.1 \%)$ \\
\hline Total / Ukupno & $47(100.0 \%)$ \\
\hline
\end{tabular}

Table 4. The frequency of issues of individual journals Tabela 4. Učestalost izlaženja časopisa

\begin{tabular}{|c|c|}
\hline $\begin{array}{c}\text { Frequency of publication } \\
\text { Učestalost izlaženja }\end{array}$ & $\begin{array}{c}\text { Number of journals } \\
\text { Broj časopisa }\end{array}$ \\
\hline Quarterly / Kvartalno & $8(17.0 \%)$ \\
\hline Bimonthly / Dvomesečno & $17(36.2 \%)$ \\
\hline Monthly / Mesečno & $12(25.5 \%)$ \\
\hline Other / Drugo & $10(21.3 \%)$ \\
\hline
\end{tabular}

Table 5. Services that the leading dental journals are available through

Tabela 5. Servisi preko kojih su dostupni vodeći stomatološki časopisi

\begin{tabular}{|c|c|}
\hline $\begin{array}{c}\text { Service } \\
\text { Servis }\end{array}$ & $\begin{array}{c}\text { Number of journals } \\
\text { Broj časopisa }\end{array}$ \\
\hline HINARI & $20(42.6 \%)$ \\
\hline Wiley Interscience & $19(40.4 \%)$ \\
\hline Science Direct & $12(25.5 \%)$ \\
\hline Free Medical & $9(19.1 \%)$ \\
\hline High Wire & $4(8.5 \%)$ \\
\hline Springer/Kluwer & $3(6.4 \%)$ \\
\hline ProQuest & $3(6.4 \%)$ \\
\hline Open Archives & $3(6.4 \%)$ \\
\hline Oxford University Press & $1(2.1 \%)$ \\
\hline Total / Ukupno & $47(100.0 \%)$ \\
\hline
\end{tabular}


Since dental journal sites always offer timely and current information, it is apparent that many publishers treat electronic instead of print versions as a main distribution channel for information. Access to articles available online in advance of print is provided by Wiley Intersience (14 journals) and Science Direct (9 journals). Therefore, 29 titles have online access to articles in press (Table 6), which is increase of $45 \%$ as compared to 2008 , when online early was available for 20 journals.

Out of total number of available journals, for only $34 \%$ print and online editions are released at the same time (Table 6). Compared to data from 2004, when more than half of available journals provided access only to current and back issues, the situation has changed and now more than half have access to articles that have been fully reviewed and edited.

However, there are small number of journals that allow access only to certain issues/articles or have publisherimposed delays (Table 6). Cleft Palate-Craniofacial Journal, accessible through aggregated database ProQuest, gives access to back issues, but with the last six months embargo period. Journal of Dental Education, published by the American Dental Education Association and available
Table 6. Availability of journal information

Tabela 6. Dostupnost informacija iz časopisa

\begin{tabular}{|c|c|}
\hline $\begin{array}{c}\text { Availability } \\
\text { Dostupnost }\end{array}$ & $\begin{array}{c}\text { Number of journals } \\
\text { Broj časopisa }\end{array}$ \\
\hline $\begin{array}{c}\text { On-line early } \\
\text { Budući radovi }\end{array}$ & $29(61.7 \%)$ \\
\hline $\begin{array}{c}\text { Current and back issues } \\
\text { Tekući i prethodni brojevi }\end{array}$ & $16(34.0 \%)$ \\
\hline $\begin{array}{c}\text { Embargo } \\
\text { Embargo }\end{array}$ & $2(4.3 \%)$ \\
\hline $\begin{array}{c}\text { Total } \\
\text { Ukupno }\end{array}$ & $47(100.0 \%)$ \\
\hline
\end{tabular}

through Free Medical Service and High Wire, provides fulltext back issues coverage, but with restricted access to articles published during the last year. Embargoes exist in Journal of the American Dental Association and European Journal of Orthodontics, but only if they are accessed from Open Access mode, or through aggregators Free Medical and High Wire.

Fully accessible archives have five journals: Angle Orthodontist (79 years), Acta Odontologica Scandinavica (71 years), Dental Materials Journal (28 years), Clinical Oral Investigations (13 years) and Clinical Implant

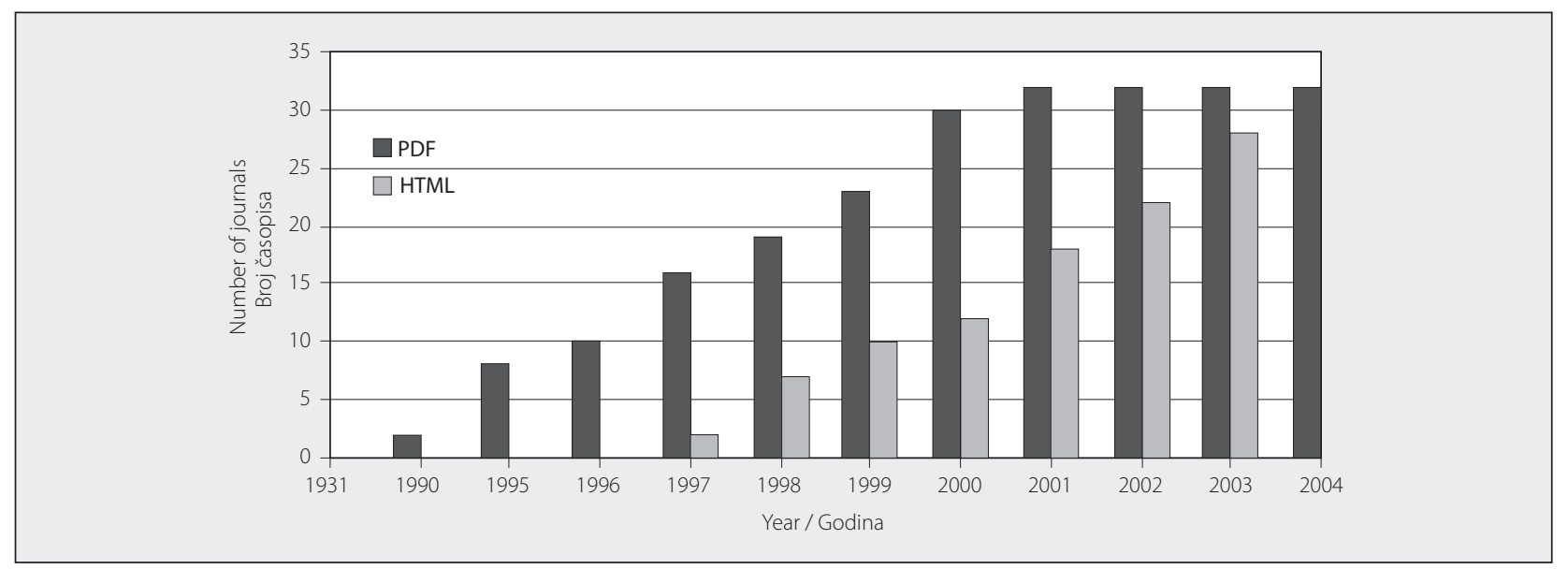

Graph 3. Frequency of formats for displaying documents in 2004

Grafikon 3. Učestalost formata za prikazivanje dokumenata 2004. godine

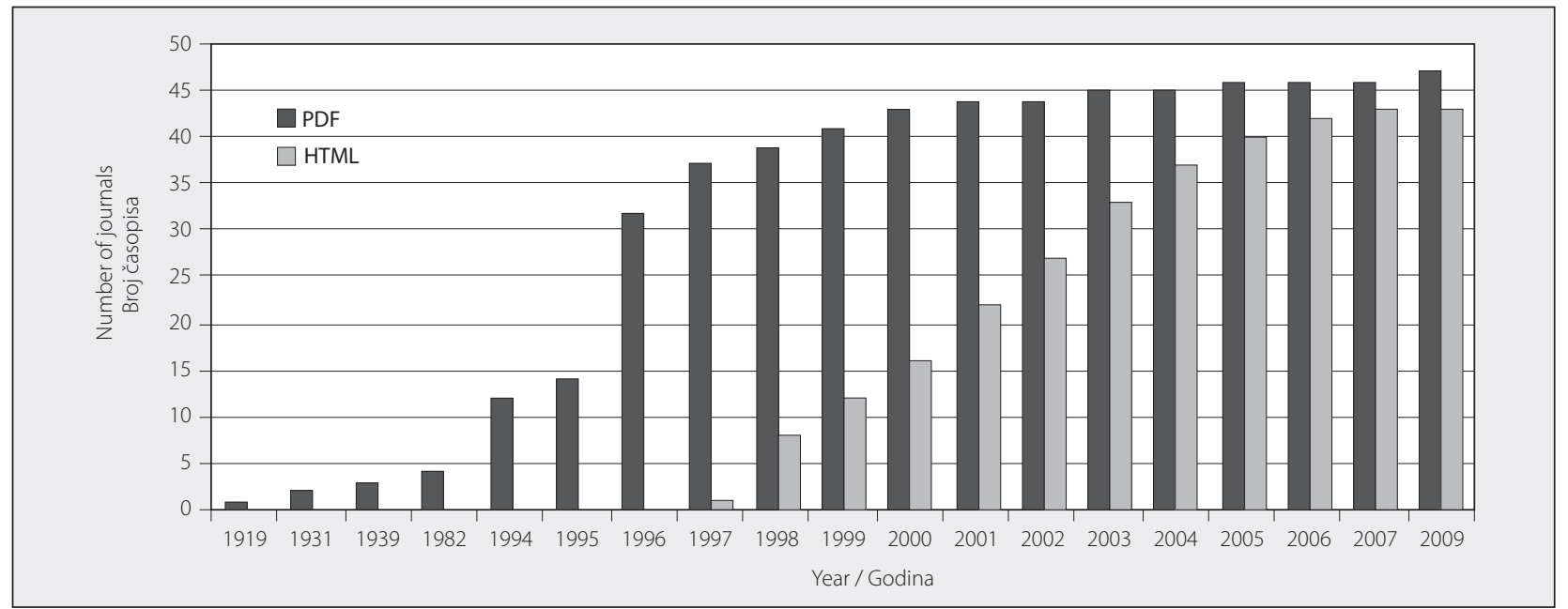

Graph 4. Frequency of formats for displaying documents in 2010

Grafikon 4. Učestalost formata za prikazivanje dokumentata 2010. godine 
Dentistry and Related Research (11 years). More than 50\% of published articles are available for 11 journals, including the Journal of Dental Research, whose archive with 93.8\% coverage refers to time period of 91 years. The remaining 31 journal have accessible smaller parts of existing full-text archives. British Dental Journal provides 11-year archive, which in regards to long journal tradition indicates low availability with only $8.5 \%$ coverage.

Providing access to high-quality publications is as well important as ensuring appropriate formats for online delivery. With more than 16 years of existence, a product of Adobe Systems Incorporated PDF (Portable Document Format) is a formal open standard, safe and reliable format for document distribution and exchange, and also very simple to use. Since PDF is used as a primary format for presenting full-text scientific articles, leading dental journals also provide all papers as PDF files, that look like original documents and preserve source file information - text, tables, illustrations, etc.

Recently, HTML (Hyper Text Markup Language) started the increasing expansion as the fastest format for displaying documents on screen. In addition to article text, HTML document includes cited references and abstracts, while graphics - photos, illustrations and tables - originally printed with the document are embedded in document structure as hyperlinks. Besides, hyperlinks to other documents can be found (author's other articles, cited articles, articles that cite an article written by the author, articles on a similar subjects, etc.).

In the field of dentistry, both PDF and HTML document formats are available for Caries Research articles published in 1997. In the following 1998, eight more journals have provided both formats too. Comparing the number of journals and size of their HTML and PDF archives in 2004 with the current state, there is an apparent publishers' tendency to retrospectively increase archives available in both formats (Graphs 3 and 4). In addition to PDF, complete available Caries Research, Journal of the Canadian Dental Association and British Dental Journal archives can also be viewed in HTML format. At present only four journals are not available in HTML: Dental Materials Journal, Journal of Dental Sciences, Journal of Orofacial Orthopedics and Odontology.

While HTML can be defined as the fastest format for displaying documents on screen, PDF remains the best format for document exchange and printing full texts.

\section{CONCLUSION}

Today, our academic community has available more quality scientific information than ever before, thanks to the Serbian Consortium for Coordinated Acquisition and enabled access through Academic Network. The fact that more than two thirds of the world's most relevant dental journals is available in this way, justifies the Consortium founders' initial idea of wide accessibility of scientific information and requires greater involvement of librarians in introducing available services to researchers in order to ensure their full utilization.

\section{NOTE}

A number of academic journals not available through Serbian Academic Network, the School of Dentistry provides from its own resources, or could be obtained at any time through the Interlibrary Loan Service, the University Library "Svetozar Markovic" in Belgrade.

\section{REFERENCES}

1. Russell JM. Scientific communication at the beginning of the twenty-first century. Int Soc Sci J. 2001; 53:271-82.

2. Vraneš A. Visokoškolske biblioteke. Beograd, Banjaluka: Konzorcijum TEMPUS projekta UMI_EPP 16059-2001; Univerzitetska biblioteka „Svetozar Marković”; Narodna i univerzitetska biblioteka Republike Srpske; 2004.

3. Kosanović BP. Coordinated acquisition of foreign scientific and technical information in Serbia: state and perspectives. Infoteka. 2002; 3:55-63.

4. KoBSON. About KoBSON. National Library of Serbia; 2010 [cited 15. 08. 2010.]; Available from: http://kobson.nb.rs/ kobson/o_konzorcijumu.1.html.

5. Web of Science. Institute for Scientific Information - Thomson; [cited 15. 08. 2010]; Available from: http://thomsonreuters. com/products_services/science/science_products/a-z/ web_of_science?parentKey=591283.

6. Journal Citation Reports. Institute for Scientific Information Thomson; [cited 16. 08. 2010]; Available from: http://thomsonreuters.com/products_services/science/science_products/a-z/ journal_citation_reports?parentKey=591283.

7. KoBSON. Electronic journals. National Library of Serbia; [cited 16. 08. 2010]; Available from: http://www.kobson.nb.rs/servisi/elektronski_casopisi.123.html. 


\title{
Dostupnost vodećih stomatoloških časopisa preko akademske mreže Srbije
}

\author{
Jelena Jaćimović1, Slavoljub Živković \\ ${ }^{1}$ Centralna biblioteka, Stomatološki fakultet, Univerzitet u Beogradu, Beograd, Srbija; \\ ${ }^{2}$ Klinika za bolesti zuba, Stomatološki fakultet, Univerzitet u Beogradu, Beograd, Srbija
}

\begin{abstract}
KRATAK SADRŽAJ
Tokom dvadesetog veka, a posebno sredinom ovog perioda, zabeležen je veliki napredak koji su postigle naučne discipline. S povećanjem broja naučnih istraživanja, naučnih radnika i uloženih sredstava eksponencijalno se povećavao i broj publikacija. $S$ razvojem informacionih tehnologija i pojavom interneta menjaju se i načini na koje naučnici međusobno komuniciraju, kao i tradicionalne uloge ustanova odgovornih za obradu i pružanje informacija. Usled velikog povećanja cena pretplata, biblioteke, iako primarni učesnici u naučnim komunikacijama, gube sposobnost da zadovolje rastuće informacione potrebe svojih korisnika. Kako bi prevazišle komercijalizaciju naučnog izdavaštva i rešile problem, biblioteke intenziviraju korišćenje različitih elektronskih izvora naučnih informacija, koordiniraju nabavku sa srodnim bibliotekama i formiraju konzorcijume. Novembra 2001. godine vodeće naučne biblioteke u Srbiji pokrenule su inicijativu za osnivanje Konzorcijuma biblioteka Srbije za objedinjenu nabavku (KoBSON). Pretplaćeni servisi, koji se finansiraju isključivo preko Ministarstva za nauku i tehnološki razvoj Republike Srbije, trenutno uključuju više od 35.000 naučnih časopisa, oko 40.000 naslova knjiga, kao i nekoliko indeksnih baza podataka. U oblasti stomatologije, oralne hirurgije i medicine našoj akademskoj zajednici je u elektronskom obliku dostupno $73,4 \%$ od ukupnog broja najrelevantnijih stomatoloških časopisa. $U$ ovom radu dat je iscrpan pregled osnovnih podataka o dostupnim časopisima: faktoru uticaja, produktivnosti, kontinuitetu i učestalosti izlaženja, jeziku, servisima preko kojih je moguć pristup, veličini arhiva i postojećim formatima. Našoj akademskoj zajednici sada je na raspolaganju više od $65 \%$ najznačajnijih stomatoloških časopisa, što opravdava početnu ideju osnivača Konzorcijuma i nalaže potrebu za što većim radom bibliotekara na upoznavanju naučnoistraživačkih radnika s pruženim mogućnostima, kako bi se obezbedila i njihova puna iskorišćenost.
\end{abstract}

Ključne reči: elektronski časopisi; stomatologija; konzorcijum biblioteka; elektronski pristup

\section{UVOD}

Komunikacija, kao suština prirode nauke, presudna je za razvoj naučnih delatnosti. Putem radova objavljenih u časopisima i saopštenih na naučnim skupovima naučnici ne samo da prikazuju svoje rezultate kolegama, već se istovremeno oslanjaju na prethodno objavljene radove, kako bi formulisali metodologiju budućih istraživanja. Naučna komunikacija, kao proces informisanja i pružanja podataka o različitim fazama istraživanja u određenim vremenskim okvirima, objedinjuje sve oblike transformacije, od nastanka početnih koncepata do njihove integracije u opšteprihvaćeno naučno znanje. Razmena mišljenja i podataka - komunikacija - zastupljena je, dakle, u svim stadijumima istraživačkog procesa [1].

Još od kraja 17. veka, kada su štampani prvi naučni časopisi, objavljivanje rezultata istraživanja čini osnovu formalne naučne komunikacije. Tokom narednih vekova, s razvojem informacionih tehnologija, struktura sistema doživljava duboke promene praćene i transformacijom funkcija i uloga uključenih aktera. Dok je naučno izdavaštvo vođeno potrebom naučnika da „objavljuju ili nestanu”, kontrolu nad sistemom sve više preuzimaju komercijalne izdavačke kuće, pretvarajući naučne komunikacije u visokoprofitabilan biznis.

Eksploatacija domena naučne komunikacije od strane izdavača dovodi do krize u samom sistemu. Istraživači gube moć nad svojim delom ustupajući ekskluzivna prava izdavačima, što vodi paradoksalnoj situaciji u kojoj ministarstva za nauku i visoko školstvo troše ogromne količine novca da bi podržala naučna istraživanja, a onda opet plaćaju velike sume da te rezultate učine dostupnim tim istim naučnicima koji su ih proizveli. Biblioteke, kao primarni učesnici u komunikaciji u nauci, sve više gube sposobnost da zadovolje rastuće informacione potrebe naučnoistraživačkih radnika.
Akademske biblioteke su tradicionalno izgrađivale kolekcije štampanih časopisa kako bi podržale obrazovne i istraživačke aktivnosti u ustanovama u okviru kojih se nalaze. Primera radi, sredinom osamdesetih godina dvadesetog veka nastavnonaučnom osoblju Stomatološkog fakulteta Univerziteta u Beogradu na raspolaganju je bilo oko 100 naslova stručnih stomatoloških časopisa. Međutim, od tog broja samo 3,8\% ostaje dostupno 2000. godine, pre svega zbog povećanja cena pretplata, stagnirajućeg budžeta biblioteke i visoke inflacije koja nas je zadesila tokom prošlih decenija (Grafikon 1).

Kako bi rešile problem, biblioteke se uglavnom okreću od vlasništva ka pristupu, od tzv. just in case ka just in time principu. Menjaju se, intenziviraju korišćenje različitih elektronskih izvora naučnih informacija, te na taj način obezbeđuju pravovremen pristup (bez obzira na udaljenost i broj korisnika), uz podržane potrebe pretraživanja i uštedu prostora za smeštaj građe [2]. Koordiniraju nabavku sa srodnim bibliotekama i formiraju konzorcijume, koji počivaju na zajedničkom cilju i interesu.

\section{KONZORCIJUM BIBLIOTEKA SRBIJE ZA OBJEDINJENU NABAVKU (KoBSON)}

Prvi pokušaj organizovanja biblioteka Srbije jeste Konzorcijum biblioteka Srbije za objedinjenu nabavku (KoBSON) [3]. Inicijativa za formiranje Konzorcijuma pokrenuta je novembra 2001. godine od strane upravnika vodećih naučnih biblioteka u Srbiji i predstavnika Zajednice univerzitetskih biblioteka i Zajednice biblioteka Srbije. Narodna biblioteka Srbije određena je za predstavnika u pregovorima, kako s izdavačima, tako is nadležnim ministarstvima. Celokupan sistem pretplate finansira se isključivo preko Ministarstva za nauku i tehnološki razvoj Vlade Republike Srbije. Priključivanjem Konzorcijuma projektu 
eIFL (Electronic Information for Libraries), omogućena je nabavka većeg broja baza podataka, odnosno elektronskih servisa, započeto je finansiranje međubibliotečke pozajmice i nabavka stranih časopisa u papirnoj formi. U planiranju nabavne politike vodi se računa o tome koje oblasti se najviše istražuju u našim naučnim, istraživačkim i obrazovnim ustanovama. Putem svoje veb-prezentacije Centar za naučne informacije i referalnu delatnost biblioteke i korisnike obaveštava o pretplaćenim sadržajima, svim projektima u kojima Konzorcijum učestvuje i organizovanju predstojećih predavanja i prezentacija. S ciljem da se izađe u susret potrebama savremenog korisnika, koji želi informacije dostupne 24 sata dnevno sedam dana u nedelji, a koje može dobiti preko mreže na svoj lični računar, zaposlenima na fakultetima i institutima omogućeno je da otvore svoj lični nalog i da preko komercijalnih provajdera pristupe ovim servisima.

Svim naučnoistraživačkim i obrazovnim ustanovama Srbije preko akademske mreže omogućen je on-line pristup velikom broju kvalitetnih informacija putem baza podataka punog teksta, koje predstavljaju sve neophodnije sredstvo za naučna istraživanja u svim delovima sveta i sredstvo relevantno za gotovo svaku predmetnu oblast. Pretplaćeni servisi uključuju više od 35.000 stranih naučnih časopisa u elektronskoj ili papirnoj formi, a od 2006. godine korisnicima je na raspolaganju i oko 40.000 knjiga i nekoliko indeksnih baza podataka. Zahvaljujući objedinjenoj nabavci, u Srbiji se sada za manje novca nego ranije pretplaćuje na znatno više međunarodnih naučnih časopisa, uključujući i one najvišeg kvaliteta [4]. Mnogi od ovih časopisa su visoko citirani naslovi, a kriterijum o citiranosti je $\mathrm{u}$ širokoj upotrebi u vođenju naučne politike širom sveta, kao i njegova primena kao pokazatelja pri izboru u zvanja, prijavljivanju za projekte i sl. Zato je danas mogućnost pristupa informacijama koje su objavljene u referisanim časopisima i objavljivanja radova u njima od velikog značaja za naučne radnike.

\section{CITATNI INDEKSI INSTITUTA ZA NAUČNE INFORMACIJE (ISI - THOMSON REUTERS)}

Citatni indeksi Instituta za naučne informacije u Filadelfiji (Institute for Scientific Information - Thomson Reuters, Philadelphia), prvobitno korišćeni kao alternativno sredstvo za pretraživanje literature, danas su najpoznatiji, široko korišćen svetski izvor naučnih informacija. Servis Web of Science, koji obuhvata sva tri citatna indeksa (Science Citation Index, Social Sciences Citation Index, Arts \& Humanities Citation Index), referiše više od 10.000 najuticajnijih naučnih časopisa, kao i radove sa više od 120.000 međunarodnih naučnih skupova [5]. Ovaj ISI - Thomson proizvod zainteresovanim korisnicima iz Srbije omogućava pristup bibliografskim podacima radova koji su objavljeni od 1996. godine do danas. Za sve časopise referisane u ovim citatnim bazama, kao i za sve časopise koji su bili citirani u njima, jednom godišnje se izračunavaju faktori uticaja (engl. impact factor) i objavljuju u okviru proizvoda Journal Citation Reports (JCR) još od 1975. godine. JCR, dobijen na osnovu praćenja više od 8.000 naslova koje izdaje oko 3.300 različitih izdavača, nudi sistematičan način za vrednovanje vodećih svetskih časopisa i njihovog uticaja na čitavu istraživačku zajednicu [6].

Kako finansiranje i aktivan broj istraživača variraju od discipline do discipline, što direktno utiče na citiranost, tako i najviši faktori uticaja u okviru različitih predmetnih oblasti nisu na istom nivou, te je ova mera jedino značajna i smislena kada se koristi za poređenje časopisa u okviru jedne discipline. Zato su svi časopisi za koje se računa faktor uticaja podeljeni u više od dve stotine kategorija (discipline prema kategorizaciji JCR).

\section{VODEĆI STOMATOLOŠKI ČASOPISI}

U kategoriji „Stomatologija, oralna hirurgija i medicina“ nalaze se 64 recenzirana časopisa s izračunatim faktorom uticaja. Ovi najrelevantniji naslovi iz oblasti stomatologije istovremeno pripadaju i nekim drugim disciplinama (Tabela 1).

Na grafikonu 2 prikazano je povećanje ukupnog broja časopisa koji su pripadali gorepomenutoj kategoriji u periodu od 1998. godine do danas.

Vrednost najvišeg faktora uticaja tokom perioda 2005-2009. godine nije se značajno menjala (raspon: 3,493-3,933).

Većina vodećih stomatoloških časopisa izdaje se u Sjedinjenim Američkim Državama i Velikoj Britaniji (62,5\%); slede Danska (17,2\%) i zemlje Zapadne Evrope (9,3\%). Izdavači preostalih $11 \%$ časopisa su iz Japana, Kanade, Brazila, Tajvana i Australije.

Podatak od izuzetnog značaja za svakog autora jeste ukupan broj radova koje određeni časopis objavi tokom godine. U okviru ove discipline 2009. godine najveći broj objavljenih radova imali su Oral Surgery, Oral Medicine, Oral Pathology, Oral Radiology and Endodontology (447) i Journal of Oral and Maxillofacial Surgery (424), dok je u okviru časopisa CRANIO - The Journal of Craniomandibular Practice objavljeno samo osam radova.

\section{ELEKTRONSKI DOSTUPNI STOMATOLOŠKI ČASOPISI}

Od 64 časopisa iz stomatologije, za 47 naslova $(73,4 \%)$ obezbeđen je pristup punom tekstu preko akademske mreže Srbije (Tabela 2). Ovo su časopisi sa, pre svega, dugom tradicijom i kontinuitetom u izlaženju. Ima onih koji traju više od jednog veka, kao što su British Dental Journal, koji izlazi od 1880. godine, i European Journal of Oral Sciences, čiji je prvi broj štampan 1893. godine. Početak izlaženja najvećeg broja naslova vezan je za osamdesete godine dvadesetog veka. Najmlađi časopis je Journal of Dental Sciences, koji izdavačka kuća Elsevier izdaje od 2006. godine (Tabela 3).

S obzirom na to da je engleski jezik danas jezik komunikacije uopšte, razumljivo je da svaki od ovih elektronski dostupnih naslova izlazi na engleskom jeziku. Sve više časopisa i u zemljama sa frankofonskog i nemačkog govornog područja izdaje se na engleskom jeziku. Archives of Oral Biology, pored svog engleskog izdanja, ima i izdanja na francuskom i nemačkom jeziku. Journal of Orofacial Orthopedics izlazi na nemačkom i engleskom jeziku, dok Journal of Applied Oral Sciences ima i englesko i portugalsko izdanje. Journal of Clinical Periodontology samo sažetke radova, osim na engleskom, štampa i na nemačkom i francuskom jeziku; Clinical Oral Implants Research sažetke objavljuje na engleskom, nemačkom, francuskom, španskom i japanskom jeziku.

Učestalost izlaženja elektronski dostupnih stomatoloških časopisa pretežno je dvomesečna. Postoje časopisi koji izlaze osam ili deset puta godišnje, dok British Dental Journal izlazi čak 24 puta. Časopis Periodontology 2000 svoje radove objavljuje tri 
puta godišnje, a Odontology samo jednom (2009. godine objavljeno ukupno 17 radova) (Tabela 4).

Svaki od servisa preko kojih su časopisi dostupni nudi razne mogućnosti pretraživanja (po oblastima koje pokriva, naslovima časopisa i sl.), uz opcije sužavanja ili proširivanja pretrage po više kriterijuma [7]. Tabela 5 prikazuje servise koji omogućuju pregledanje i preuzimanje radova objavljenih u vodećim stomatološkim časopisima in extenso.

S obzirom na to da su informacije koje se nude na internetstranicama stomatoloških časopisa uvek pravovremene i sveže, jasno je da veliki izdavači sajtove elektronskih verzija svojih izdanja danas tretiraju kao glavni distribucioni kanal informacija objavljenih u njima. Tako mogućnost pregledanja i pristupa budućim izdanjima, odnosno sveskama koje će se tek pojaviti u štampi, pružaju Wiley Intersience (za 14 časopisa) i Science Direct (za devet časopisa). Dakle, za ukupno 29 naslova postoji obezbeđen on-line pristup radovima koji se nalaze u pripremi za štampu (Tabela 6), što u odnosu na 2008. godinu, kada je on-line early bio dostupan za 20 časopisa, predstavlja povećanje od $45 \%$.

Za samo 34\% ukupnog broja elektronski dostupnih naslova on-line izdanje postaje dostupno istovremeno kada i štampano, odnosno za ukupno 16 časopisa uvek su na raspolaganju u punom tekstu tekući i prethodni brojevi (Tabela 6). U odnosu na podatke iz 2004. godine, kada više od polovine časopisa nije imalo on-line early izdanje, situacija se izmenila i sada više od polovine ima obezbeđen pristup radovima koji su dobili pozitivnu recenziju.

Postoje i oni naslovi koji omogućavaju pristup samo odabranim sveskama, odnosno radovima ili s određenim periodima odlaganja korišćenja koje nameću izdavači. Međutim, broj takvih naslova je mali (Tabela 6). Cleft Palate-Craniofacial Journal, kojem se pristupa preko agregatora ProQuest, omogućava pristup arhiviranim brojevima, ali sa „embargom” na poslednjih šest meseci. Journal of Dental Education, koji izdaje American Dental Education Association i koji je dostupan preko servisa Free Medical i High Wire, ne dozvoljava pristup radovima objavljenim u toku poslednjih godinu dana, dok su svi prethodni brojevi u slobodnom pristupu. Ovakva zabrana pristupa postoji i kod publikacija Journal of the American Dental Association i European Journal of Orthodontics, ali samo ako im se pristupa iz tzv. otvorenog režima (open access), odnosno preko agregatora Free Medical ili High Wire.

U potpunosti dostupne arhive ima pet časopisa: Angle Orthodontist (79 godina), Acta Odontologica Scandinavica (71 godina), Dental Materials Journal (28 godina), Clinical Oral Investigations (13 godina) i Clinical Implant Dentistry and Related Research (11 godina). Više od 50\% objavljenih radova dostupno je u slučaju 11 časopisa, među kojima je i Journal of Dental Research, čija arhiva, sa $93,8 \%$ pokrivenosti, obuhvata vremenski period od 91 godine. Preostali 31 časopis pruža mogućnost pristupa manjem delu svojih arhiva. British Dental Journal je publikacija sa najmanjom dostupnom arhivom (11 godina), što u odnosu na dugu tradiciju časopisa čini samo 8,5\%.

Veoma je značajno obezbediti kvalitetne publikacije, ali je isto tako važno i u kojem obliku su one elektronski dostupne. $S$ nešto više od 16 godina postojanja, proizvod PDF (Portable Document Format) kompanije Adobe Systems Incorporated danas je standard; siguran, pouzdan format za distribuciju i razmenu dokumenata, jednostavan za korišćenje. Kako se PDF koristi kao primarni format i za prikazivanje punih tekstova iz naučnih časopisa, tako su i svi radovi vodećih stomatoloških časopisa dostupni u ovom formatu, koji obezbeđuje izgled članaka onakvim kakvi su originalno objavljeni, sa svim tabelama i ilustracijama i identičnim rasporedom iz štampane verzije.

U poslednje vreme se sve češće primenjuje HTML (HyperText Markup Language), najbrži format za pregledanje dokumenata na ekranu. Uz kompletan tekst članka, ovaj format uključuje citiranu literaturu i sažetke, ali ne i grafiku (fotografije, ilustracije i tabele) koja je originalno štampana sa dokumentom, koja se prikazuje putem odvojenih hiperlinkova. U okviru ovog mrežno strukturiranog dokumenta, osim ovih, javljaju se i hiperlinkovi do drugih dokumenata (ostalih radova autora, citiranih članaka, radova u kojima je taj članak citiran, radova slične tematike itd.).

U oblasti stomatologije, osim u PDF-u, radove časopisa Caries Research objavljene 1997. godine moguće je pregledati i u HTML formatu. Naredne 1998. godine još osam časopisa obezbedilo je i ovaj format. Poredeći stanje iz 2004. godine, odnosno broj časopisa i veličine njihovih HTML i PDF arhiva, sa današnjom situacijom, jasna je težnja izdavača da retrospektivno uvećaju arhive i obezbede pristup radovima u oba formata (Grafikoni 3 i 4). Osim u PDF-u, kompletne dostupne arhive časopisa Caries Research, Journal of the Canadian Dental Association i British Dental Journal moguće je pregledati i u HTML formatu. $\mathrm{U}$ ovom trenutku radovi iz samo četiri časopisa nisu dostupni u HTML formatu: Dental Materials Journal, Journal of Dental Sciences, Journal of Orofacial Orthopedics i Odontology.

Dok se HTML zaista može definisati kao najbrži format za pregledanje dokumenata na ekranu, PDF ostaje najpovoljniji format za njihovu razmenu i štampanje u punom tekstu.

\section{ZAKLJUČAK}

Našoj akademskoj zajednici sada je na raspolaganju više kvalitetnih informacija nego ikada pre zahvaljujući servisu KoBSON i omogućenom pristupu preko akademske mreže. Činjenica da je više od dve trećine najznačajnijih stomatoloških časopisa dostupno ovim putem opravdava početnu ideju osnivača Konzorcijuma i nalaže potrebu za što većim radom bibliotekara na upoznavanju naučnoistraživačkih radnika s pruženim mogućnostima, kako bi se obezbedila i njihova puna iskorišćenost.

\section{NAPOMENA}

Veći broj časopisa nedostupnih preko akademske mreže Srbije Stomatološki fakultet obezbeđuje iz sopstvenih sredstava, dok se preostali nedostupni radovi u svakom trenutku mogu dobiti putem inostrane međubibliotečke pozajmice koju sprovodi Univerzitetska biblioteka „Svetozar Marković” u Beogradu. 